\title{
THE DEMOCRATIC CONTROL OF MILITARY FORCES
}

UDC 321.7:355.015

Smail Oštraković ${ }^{1}$

355.1:321.7

Faculty of Philosophy, University of Tuzla

Received: 21.04.2011

Accepted: 24.05.2011

\begin{abstract}
The transition requirement for post communism countries, especially the part that is about military forces is to establish those civil-military relation that will have prepared projects for awareness evolving of society and military about necessity of democratic control over military sector of country through development of many different communication forms and shapes. Before everything, it means the entire freedom and independence of media at access to military forces as the topic and subject of its interests and also the organization of public military communication system as integral part of information-communication system in society.
\end{abstract}

Keywords: demographic control, military forces.

\section{INTRODUCTION}

The wide discussion of this area requests answering next questions:

1. What democratic control of military forces means to entire society and to military forces separately, what means to harmonize two at first sight opposite imperatives, functional (society needs the military to be protected from eventual outside danger) and social which represents the ideological or value aspect?

2. How the process of military forces control in society, in parliamentary democracy conditions is established? Is it the simple subordination to the government, the parliamentary procedure that is exposed to judgment of publicity and how much it considers the inclusion of military ac active information source through the channels of public communicating?

3. How much is the process continuous and controlled, how much is important to have the constant flow of actual, truthful, objective information, which could help citizens to establish their influence on military force in country?

Public media, in this level where they are in entire democratic changes function can strength and mirror the certain state at most of mentioned questions.

1 Correspodence to:

Smail Oštraković, MSc, Faculty of Philosophy, University of Tuzla Phone: +38761734104 
Taking into the consideration the importance of mentioned area and need of every actual government to synchronies all important society functions, some of basics factors seem to be of an influence to contents of democratic control, and that are:

1. The history of civil-military relations

2. Political, economic and social conditions in country

3. International status

4. Legislative in country

5. Military professionalism and military culture

\section{DEMOCRACY}

Democracy is very difficult to define as a notion, because the meanings of it are changed from age to age and also from one ideology to another. However, we can talk about democracy wherever the most of people has a freedom and rights on political choice, the observing and call to responsibility of the state government. This civil position is based on believe that all state government comes from people and severs people as only real sovereign. So, the base of democracy is people sovereignty, which in modern world is also present as an idea of national sovereignty.

The people, as the basics of democracy are always only political people, and they are consisted of citizens (lat. Cives, franc. Citoyen) or with persons that have equal political rights. There are two main history types of democracy: antic and modern, so in relation to them there is difference between direct and indirect, formal and real, political and social (Held, 1990).

From many basics elements of democracy, I will mention the one that are important for this survey, the one that are necessary to call the society "democratic". To enable citizen to influence on state government, as political subject the citizen have to have enough knowledge about facts that are related to political actions.
Before everything it is necessary for citizen to have knowledge about its own interests and the interests of social group that it belongs. This knowledge is needed to harmonize interest as much as possible, without major interest confrontation with other citizens and entire society (Held, 1990).

Material security of citizens, as the basic condition of every democracy is the basic for self action in political life and the influence on state government.

To enable citizen to successfully make political decisions and to act in establishing, supervising and calling to responsibility the state government, and also to make every man feel safe for its life, work, property and human dignity it is necessary to have and respect an array of democratic rules and mechanisms. These rules are permanently defined by constitution of a country, as the highest expression of people sovereignty.

Especially important rules are the one that define basic freedom and rights of citizens, that are confirmed by international papers as are Universal declaration about human rights (OUN 1948), and two international pacts about human rights (1966).

Understanding like this stays in the shapes of classical interpretation that is present at many thinkers:

Pericles: "The democracy is determined by shape in which the rule of majority is present, in which the citizen are equal by law, but the advantage has the one that has a good reputation (value of a man) in community, and not the one that belongs to certain fraction"(Fočo, 2000).

Herodotus: "The rule of people is as a name something the most beautiful in the world, which before everything means the equality for all. The things that happen at monarchy do not happen at democracy" (Held, 1990).

Herodotus sees everything in the mass of people, the power and the will for a country that they need. 
According to him the deficiencies of people rule are at ignorance of people and in the disorder in the process of social business ruling.

Spinoza follows the taught that democracy is the nearest way to transmit and realize the natural rights to social community.

Spencer determines democracy as political organization shaped according to rule "equal freedom for all", while parliament is executable government.

Because of that, at certain nations that have no freedom of behavior and internal restriction developed, there is no place for democracy.

To enable democracy function, not only high moral feeling is necessary but enough level of intelligence and conches about the value of freedom. By that way the citizens will be ready to use their right of voting, which would represents the ideal type of government (Barnes).

David Held finds that democracy is the presence of some shapes of political equality between people, which are said at "the rule of people".

According to mentioned definitions of democracy it is possible to generalize that democracy is the need of people in community for their interpersonal cooperation with target to achieve rights and freedom and also the responsibility for participating in the processes and the concern for rights of other. By that way the democracy is taken up to level of social value and moral principles.

The freedom and rights that is the subject of interests of modern democratic society are promoted to highest ideals and the intention of citizens. Every person should intent to make its contribution for establishing rights and freedom by learning and upbringing next generations.

Onto this definition of democracy also relays the choice of certain country as a country where the government is responsible in front of people, and that government that is consisted and chosen through free multiparty elections in which all citizens has the same right for voting, and citizen and political rights are granted by law.

The existence of order like this considers written and transparent procedures for government work, including restrictions as the basic prediction for possibility of control executing. By that way one of the basic postulates of democracy is realized, so everyone that have political power are responsible to ones that chose them and in whose name they implement defined politics. Because of that, only democratic chosen government has legitimacy to lead politics, including the security and defense politics, and also to control institution of defense in state level and call for responsibility the elected ones.

\section{DEMOCRACY CONTROL}

Although, in the most developed democratic countries, the area of defense is mostly covered with exclusivity of the government power, and is out of the range of influence of the society, still the democratization trend of the government power, including military is resulting in regulation of the defense system by constitution.

That way democratic accomplishment in the area of defense is conceptualized in the constitution, and it is not under control of the state bureaucracy, nor the party leaders.

Although, in the post-communistic countries it is inevitable that the department of military and defense is more exposed to control of the democracy, aiming to take shape of the will of people in the area of inland, and external policy.

Therefore the purpose of democratic control of the army is to preserve elementary values of the civil society, which is the purpose of existing government and state. 
There are two types of potential dangers, which should be prevented with democratic mechanisms and procedures: first, politicians that have ambitions to use the military to accomplish their own political goals, and second, the military personnel that have political goals.

\section{CONCLUSION}

Democratic control means that defining and implementing of defense politics is open for active participation of all citizens, and also ensures the ruling access that is achieved through function of public opinion.

In modern democracy public opinion is not only used through possibility of public inclusion of citizen in democratic control of military (through public opinion), but by the way that society functions in this area are enabled through establishing communication channels as through establishing the structure of civil society.

\section{REFERENCES}

Held, D. (1990). Democracy Models. Croatia, Zagreb: Školska knjiga.

Fočo, S. (2000). Sociology, second added edition. Bosnia and Herzegovina, Zenica: Dom štampe. 